\title{
"I'll Have you Sent to Confino": How the Fascist Regime Punished and Repressed Homosexuality
}

\begin{abstract}
This chapter explains the extent to which liberties of every individual had been restricted by the regime. It focuses on censorship and the so-called moralisation campaign to show how the regime had managed to invade its citizens' private lives. The situation in Turin is used to exemplify what went on at a national level in terms of repression. The second part concentrates on repression of sexuality and homosexuality: although homosexuality was not mentioned by the Code of Laws, a number of legal measures existed and were deployed to repress and punish it. The intention is to depict the climate that surrounded G. in the last days of his "freedom", as his world was shrinking and becoming increasingly dangerous.
\end{abstract}

Keywords Censorship $\bullet$ Repression $\bullet$ Moralisation $\bullet$ Dissent $\bullet$ Confino

This chapter explains the extent to which liberties of every individual had been restricted by the regime. Based on research in the Turin Prefettura Archives and on newspapers articles of the period, it focuses on the socalled moralisation campaign and on how much the regime had managed to invade its citizens' private lives. The situation in Turin is used to exemplify what went on at a national level in terms of censorship and repression. The second part of the chapter concentrates on repression of sexuality

(C) The Author(s) 2019

G. Romano, The Pathologisation of Homosexuality in Fascist Italy,

Genders and Sexualities in History, https://doi.org/10.1007/978-3-030-00994-6_5 
and homosexuality, explaining how it was punished. The intention is to depict how G. must have felt, the climate that surrounded him in the last days of his "freedom", as his world was shrinking and becoming increasingly dangerous.

If G. had bought La Gazzetta del Popolo the day of his arrest and subsequent internment, he could have not failed to notice that its appendix novel was entitled "You will suffer", ${ }^{1}$ a rather grim omen. However, it is unlikely: La Gazzetta del Popolo was a lower middle-class readership paper, with a distinctive popular press flair and it would have probably not been the choice of a university-educated person.

G. is much more likely to have read La Stampa, the first and most authoritative newspaper in Turin. On 22 November Seventh (which means 1928: the calendar now had to be counted on the years Mussolini had been in power) La Stampa offered a totally rosy picture of current events. This is hardly surprising: in a Prefettura note both La Stampa and La Gazzetta del Popolo are said to be completely in line with the regime's directives, ${ }^{2}$ as was most of the Italian press by 1928 . The paper that day informed its readers that the government was tackling unemployment, while Anti-fascism was almost defeated as another fuoruscito, a term that indicated those who managed to expatriate in order to escape from persecution, had been arrested in Belgium and an anti-Italian plot had been discovered in Gorizia, at the border with Slovenia. The paper could conclusively state that the regime's opponents were now in "the last trenches". 3 In prominent position, there was an update on the archaeological discovery of some ancient Roman ships in the Nemi Lake. ${ }^{4}$ Mussolini's propaganda boosted the ideal connection between present Italy and its glorious past, the Roman Empire. Any significant archaeological discovery was used to fuel national pride and ambition for colonial expansion. The other pages of La Stampa gave accounts of local police forces' successful efforts, official visits, inaugurations and sport events. Among the "soft news" that increasingly filled papers' pages, a report on a residents' campaign against an invasion of pigeons in the central piazza Carignano that had pushed another group of citizens to defend the pretty birds. ${ }^{5}$

In the meantime, the infamous Tribunale Speciale, instituted in 1926, was busy: in only one day Laura Cavallucci, a Turin typographer who had agreed to print anti-regime leaflets, was sentenced to a year in prison, Salvatore Capogrossi received a 10-year sentence for trying to revive a branch of the Communist Party in a small village near Rome, and Giuseppe Barletta got four years behind bars for distributing Battaglia Sindacale 
(Trade Union Battle), a paper that was officially banned. ${ }^{6}$ Disproportionate punishment, together with the discretionary way it was inflicted, has been identified as a tool of fascist repression in itself, that kept the population in a state of constant terror. ${ }^{7}$

However, a non-sympathiser of the PNF would have probably read the paper from a different perspective: the frequent arrests of anti-fascists meant that opposition to the regime had not been totally uprooted as claimed by propaganda, while Italian fuorusciti continued their political activity abroad and linguistic minorities, reluctant to accept the imposition of having to speak the Italian language, resisted.

Nevertheless, even reading between the lines, the picture must have looked bleak. From 1926 onwards Turin, like the rest of the country, had undergone what was called "epurazione", a moralisation campaign which masked tough censorship of any dissenting voice: publishers and bookshop owners were tried in court for printing and selling books now described as offensive towards the common sense of decency, ${ }^{8}$ among them Sappho's and Anacreon's poems. La Stampa titled "Literature unsuitable for young ladies ends up in court" "where even the headline avoided the words "indecent" and "scandalous", opting for a softer expression, to be on the safe side.

Turin ballrooms had been a main target. La Gazzetta del Popolo reported:

In all major Italian towns, the public security authorities, following precise government directives, have implemented a vigorous purge and surveillance on ballrooms, and, particularly, on those clubs or venues where dancing could mask less legal intentions on the part of those who frequent them. (...). Apart from finding an incredible number of under-age girls, [the police] discovered some past-times that had hardly anything to do with dancing. (...) It is fatal that these young girls with very little experience and a lot of vanity, when in contact with equivocal and vice-ridden people, in environments where morality and good habits are too ... absent, slide into vice and perdition. ${ }^{10}$

The journalist added that in the last few days eight dance-halls had been closed and six more were under police investigation, while, according to the article, in 1925 alone 40 clubs had been closed and 17 fined, together with 29 hotels and 17 affitta-camere (short-let accommodation). Several police raids had taken place in Turin's dance schools, dance-halls and similar clubs and many teenagers, particularly girls, had been brought to 
the local police station, where they had been handed over to their parents as a sign of warning. ${ }^{11}$ All this was confirmed by the local Prefettura correspondence with the Ministry of the Interior:

Necessary to eliminate this shame, deplored even by authoritative press clubs and so-called dance schools constitute dangerous hotbeds of moral infection for adolescents. (...). ${ }^{12}$

The Ministry of the Interior warned local Prefetti of other dangerous forms of entertainment, such as the so-called tabarin, a type of stage performance similar to a varieté show:

In recent years, a kind of entertainment of exotic origins (...), the so-called tabarin has been introduced in our country. It is unnecessary to mention that such a type of entertainment, for its character and for the public that follows it, among which people with little or no morality, is a source of corruption and vice, and always constitutes a serious danger for young people who are more prone, because of their young age, to be hit by the pernicious impressions of equivocal environments (...). ${ }^{13}$

The moralising campaign, which dated back to the beginning of the regime, now extended to all forms of entertainment, even music: jazz was a major target. Based on improvisation, it increasingly was associated with rebel attitudes and potentially immoral, promiscuous night-clubs, something that found a strong echo in the local newspapers. ${ }^{14}$ Besides, it was "foreign" and, as such, it raised suspicions just like other "imported" trends, such as Feminism, considered as quintessentially American. The country had to be self-sufficient and focus on its traditions and history. Even foreign names had to be translated and "Italianised": Albrecht Dürer became a desolately provincial "Alberto Durero", to quote an example taken from a magazine of November $1928 .^{15}$

However, from the killing of the socialist MP Giacomo Matteotti in 1924, the repression had touched many other aspects of public and private life, and in 1926 had reached its peak: Law n. 2307, approved on 31 December 1925, aimed at "the integral fascistisation of the press". ${ }^{16}$ The control of newspapers and magazines was a top priority and the Prefettura was given full powers to intervene when a publication was thought to be irreverent or critical of the regime. This clearly was reflected in the situation in Turin. Main newspapers and magazines in circulation in 1928 in Piedmont were La Stampa, La Gazzetta del Popolo, Il Momento, Il 
Piemonte, Il Primato and Il Giornale dei Combattenti: the first four were described by the Prefettura as "favourable to the current political policies", while the latter two were said to be "even more favourable". ${ }^{17}$ Local voices of dissent such as Ordine Nuovo, Altoparlante, La Plebaglia, Umanità Nuova had already disappeared, Il Baretti, founded by the famous Turin anti-fascist intellectual Piero Gobetti, published its last issue in Autumn 1928, La Protesta and La Riscossa would cease publication in 1929. ${ }^{18}$

In addition, several cultural associations, perceived as uncontrollable and potentially hostile to Fascism, were forced to disband: from cradle to grave, the state now offered a number of options where sport and socialisation could take place under its vigilant eye. This can be observed at a local level too. By 1928 many cultural associations in the Piedmont region had been dismantled, among them the Italian Federation of Workers of the Publishing Sector (Federazione Italiana dei Lavoratori del Libro) and the Literary Club (Circolo Letterario) in Torre Pellice, the small town where the majority of Italian Protestants lived. The latter is an unequivocal indication of the level of censorship and persecution of religious minorities that the regime had started implementing. ${ }^{19}$

As Ebner's research shows, ${ }^{20}$ everywhere throughout Italy many osterie and trattorie, a traditional meeting place for working class people, had been forced to close, often the result of spying activities: the ones that continued to operate were full of informants ready to over-hear antiregime comments, more easily pronounced when under the influence of alcohol. Sometimes the owners and staff had been recruited as informants, on the promise that they could continue their activity without too many bureaucratic entanglements. Hotels, identified as a primary meeting location for anti-fascists, had been regularly searched, fined or shut down. Again, this happened in Turin as well and the local Prefettura files are full of correspondence, to and from the police (both polizia politica and normal police), regarding surveillance of public places: a bottiglieria (unsophisticated wine bar) in via Principe Amedeo was brought to the Prefetto's attention on 10 January 1929 because "the worst kind of Turin antifascists gather there", but after investigation, charges were dismissed. However, on 17 May 1929 the polizia politica wrote to him again as

another confidential source reiterated to the Ministry that B.R.'s bar, situated in Turin in via Principe Amedeo [...], is a gathering place for known antifascists, who are regularly engaged in anti-regime propaganda. One of the 
most excited preachers and slanderers would be B.R. himself, although he allegedly declared on many occasions he is a police informant. ${ }^{21}$

Evidently, spying had become the norm and suspicion surrounded everything and everybody, to the extent that even the police were sometimes uncertain of their own informants' loyalty.

In Turin and elsewhere space for independent cultural activities was shrinking, social life had been drastically reduced, entertainment was monitored, censorship was in full swing in every sector, including books, newspapers, theatre and cinema. ${ }^{22}$ Paradoxically, even coriandoli, the traditional coloured pieces of paper thrown in the streets at Carnival, had been banned by a local Prefettura decree. ${ }^{23}$

Furthermore, the regime had started to interfere with the most intimate sphere of its citizens' life, indicating that private choices had to be submitted to the nobler common cause. Sexuality, family and the sphere of affections were now an important part of the life of the state and had to serve the demographic campaign. The tax on celibacy, approved in $1926,{ }^{24}$ imposed a payment on unmarried men between the age of 25 and 65 , but its burden varied with the payer's age: 35 lire per year for those between 25 and 35, 50 lire for men aged 35-50, 25 lire between the age of 50 and $65 .{ }^{25}$ In 1928, in compliance with eugenics theories, an amendment was being discussed in Parliament on whether deaf, mute, disabled, paralysed and blind men were to be exempt from payment, as only healthy people were to be encouraged to procreate. It was approved in January 1929. Abortion and contraception were outlawed in $1930^{26}$ but long before they were already depicted as being immoral and selfish activities, essentially against fascist ideals: the advertisement of contraceptive devices had been banned by the Public Order Law in 1926. The message was unequivocal: the fascist regime wanted to be perceived as the order-making force which would push every excessive and non-conforming behaviour out of the picture, through the imposition of a very strict code of morality. As Dunnage acutely observed: "'Moral order' was to be considered the best guarantee for 'public order'". ${ }^{27}$

The dictatorship had almost managed to silence dissent, to impose its moral laws and its code of behaviour, although not completely. Women continued to use contraception: as Passerini argues, in many cases the use of "induced sterility" instruments, such as condoms, or methods such as coitus interruptus gained the connotation of a form of rebellion. ${ }^{28}$ The tax on celibacy seems to have gathered little consensus and there must have 
been a high number of evaders, as in 1929 the state felt the need to introduce the legal duty for employers to report unmarried members of staff to the authorities, in an attempt to frame tax-dodgers. ${ }^{29}$ Several popular songs ridiculed the tax, showing how unpopular it was. One of them went $^{30}$ :

So, dear bachelor colleagues / let's always remain bachelors / and if the taxes increase / we will happily pay them / so that we will always be free. / We'll sleep with dolls / and instead of walking around with our mother-inlaw / we'll happily stroll in the company of a poodle.

In 1937 it was necessary to link success in state careers to marriage and the number of children one had. ${ }^{31}$ In Turin there was even a desperate attempt to start a solidarity campaign, hoping employers and private home-owners would provide accommodation and jobs to young, potentially child-bearing couples. ${ }^{32}$ Despite all this, birth-rates inexorably continued to fall and Mussolini's elegant 1930s' statement "Children or you'll be beaten up with a stick" (in Italian "Figli o legnate") ${ }^{33}$ clearly shows his consequent irritation. For all the slogans, the official congratulations to mothers of twins and the cash rewards to prolific mothers, in Northern Italy births kept decreasing steadily, from 26.6 every 1000 residents in 1921-1925 to 19.8 in $1936-1940 .{ }^{34}$ Finally, the urge to gather, dance and have fun seems to have continued undeterred, despite impositions and limitations, as by the end of 1929 in a medium-size town like Turin there still were 51 dance-halls open and functioning. ${ }^{35}$

Most importantly, in the Piedmont capital and elsewhere, many citizens still found the courage to voice their dissent: in 1930 the owner of a photographic shop, "according to information received by a confidential source (...) spoke incessantly and in very vulgar terms about the Regime [capital letter in the original]". ${ }^{36}$ In the same year, at Caffè Roma, run by the B. Sisters, informants reported constant hostile comments being pronounced against Fascism; but reading other anonymous letters, all scrupulously filed and investigated, one learns that this also happened at Caffè Romano, Frejus, San Lorenzo, Delle Provincie, Galliari, Consolata, Piemonte and Baio. Several hotels in Turin were kept under special surveillance, which suggests that the authorities were aware of anti-fascists' gatherings taking place in some of them, and frequently people reported anti-regime chants and writings on walls of the town's buildings. ${ }^{37}$ Ustica, Lipari, Ponza and other Italian islands increasingly were full of detainees 
sent to confino for having pronounced phrases against Mussolini ${ }^{38}$ and so were mental health hospitals. ${ }^{39}$ Finally, despite the tight grip of censorship on the press, in 1937 Dino Alfieri, Secretary of the Press and Propaganda Ministry, still considered it necessary to issue written directives to the journalists of satirical magazines, to remind them that "the satirical press has the precise duty to target all behaviours that are not in harmony with the ways of life taught by Fascism". ${ }^{40}$ Clearly some out-of-line life-styles and some criticism against the regime persevered.

However, at the end of 1928 , for a man like G. the world had not just shrunk significantly, it had become dangerous too. Homosexuality was not mentioned by the Zanardelli and the Rocco Codes of Law, and an amendment that would criminalise it was never approved. Nonetheless, men who had sex with men were sued for a variety of crimes such as scandalous behaviour, prostitution, soliciting prostitution, obscene acts in public, rape, assault, abuse of minors and offence to sense of decency, among others. There was a difference of penalties given to so-called "habitual" homosexuals and those who engaged in same-sex acts occasionally, thought to have been "infected", badly influenced, driven by circumstances and not by their nature. It made a lot of difference if the vice was congenital or acquired because in the first instance a cure would be almost impossible. Equally there was a difference between a passive or an active homosexual, habitual or casual, ${ }^{41}$ and if there was visibility, ostentation or discretion. ${ }^{42}$ Most historians who addressed this issue ${ }^{43}$ have underlined the difference in sentences, showing that the maximum penalties were given to those who were identifiable and were considered to be "passive pederasts". Some have also indicated the social class and status element as another decisive factor and it has been correctly emphasized that most of the homosexuals sentenced to confino came from the lower social classes. Equally, it has emerged with clear evidence that there was a level of tolerance of those individuals who kept their homosexuality quiet, hidden, without making big public statements.

Sanctions varied from confino, confinement on a small island or in a small village usually in Southern Italy for up to five years, to ammonizione, an official warning which implied that the person in question would have to sign in, morning and evening, at the local police station and could not leave the town of residence; to diffida, a more serious type of sanction that meant the person was told officially that if caught committing the same crime again, conviction would ensue. For certain crimes there was imprisonment and many are likely to have ended up in prison for crimes con- 
nected with homosexuality: the Bollettino della Scuola di Polizia Scientifica provided a list of more than 1000 individuals jailed as "homosexual offenders" in Rome alone between 1927 and 1939. ${ }^{44}$ In addition, the police could incarcerate and question anyone at their discretion and used these measures against homosexuals too. ${ }^{45}$ One older gay man who accepted to be interviewed in the late $1990 \mathrm{~s}^{46}$ confirmed this. He said that during the Ventennio he was frequently arrested, kept in the local police station, sometimes for days, and then released. There was no trial, no warrant, no interrogation and no official order of arrest, it all seemed to be completely at the discretion of the local police and it was possible, as rightly observed, because "legislation deprived citizens of legal protection against the arbitrary behaviour of the police". ${ }^{47}$ The interviewee also testified that, being known to the authorities as a pederast, he was often arrested in towns he was visiting, and sent back to Naples, where he resided, with no particular charge. These measures seem to have been imposed as deterrents and as warnings. Ebner reconstructed another similar case, that of Guglielmo, a 22-year old Florentine man who was known to the local police since he was 14 years old:

Guglielmo's lengthy criminal record consisted mainly of several charges of extortion and numerous police citations for "pederasty". He had been assigned to diffida and ammonizione several times in the late 1920s for being a 'vagabond' and a "pederast". From 1926 to 1939 he was arrested and detained 13 times, usually for "being in the company of suspected pederasts". ${ }^{48}$

Confino, like all other sentences, was imposed arbitrarily. As Emilio Lussu wrote at the time:

the confino di polizia is the regime's masterpiece: the danger of being sentenced to it is dangling above us all. (...) The sentence is for few, the threat is for everybody. ${ }^{49}$

As homosexuality gradually became associated with a crime against "race", it acquired stronger political connotations and sentences to confino for men who had sex with other men intensified. Scholarship has associated this phenomenon with the introduction of racial laws in 1938. However, there is ample evidence that persecution through this type of sentence started much earlier: G.'s memoriale is further proof that already in 1928, to accuse somebody of pederasty was believed to lead automatically to a 
confino sentence. Confino and domicilio coatto (home arrests) dated back to the Liberal State and so did the societal prejudice against homosexuality. There is some "continuity between fascist Italy and the previous Liberal State, in the context in which Mussolini's policies in the sphere of gender and sexuality largely represented a reinforcement of pre-existing ideas and norms" ${ }^{50}$ It is interesting to note that continuity with the previous body of laws served several purposes. It did not draw attention to the crime in question and at the same time it allowed the state to harden pre-existing legislation without alerting the population of a drastic change of policy. ${ }^{51}$ In essence, it was a quick short-cut to introduce changes through the Prefettura's special decrees or to "creatively" interpret pre-existing legislation.

However, it is certainly possible to argue that stereotypes of effeminate men $^{52}$ were pushed to the extremes during Mussolini's dictatorship and that this form and extent of persecution of homosexuality had never taken place in unified Italy before. The ideas existed before Fascism, but not the actions to implement these ideas to their logical and extreme conclusions.

Il Duce himself had declared: "confino is social hygiene, national prophylaxis. Society isolates these individuals like the doctor isolates infectious patients"; it was a "social laxative that helps the country get rid of numerous and dangerous influences". ${ }^{3}$ G.'s brother, a doctor, would have been very familiar with these metaphors and, as a proud selfproclaimed fascist, would have probably agreed on their meaning in principle.

Unfortunately, it is impossible to reconstruct with precision the persecution of homosexuality in Turin during Fascism as all the police files have "disappeared" for the years 1922-1943: the silence imposed by the regime has remained almost intact until the present day. Not to ever mention homosexuality had the precise intention of denying its existence: it was tolerated to a certain degree, only as long as it remained invisible. ${ }^{54}$ The repressive action of the state could take place in a hidden, subtle way that was-and still is-difficult to pin down. Silence was also meant to protect Italians from ideas that could negatively influence them: in the same way, suicide was not to be mentioned because, as Mussolini telegraphed to the Italian Prefetti in 1926, to talk about it publicly would constitute "a dangerous suggestion for the weak or weakened spirits". ${ }^{55}$

Unsurprisingly, there is only sporadic mention of homosexuality in the Turin newspapers analysed. Shortly after G.'s arrest, a young man, accom- 
panied by some of his friends, was reported to have stopped another man in a street in Turin and to have asked him for money not to reveal he had approached him sexually in Parco Michelotti. At his refusal, the blackmailer and his friends had paid a visit to the man's wife, managing to obtain five Lire from her in exchange for discretion. Later, however, he still denounced the man, but a member of the gang retreated, saying that the story was a complete fabrication and the police accepted this version of the facts. ${ }^{56}$ Clearly, as the stigma around homosexuality hardened and same-sex relations were pushed underground, homosexuals became easy prey of blackmailers.

Scattered here and there, in the local press and in the Turin Prefettura files, there is mention of "different" people that leaves little doubt about the kind of censorship society imposed: a successful woman entrepreneur who never liked dolls as a child and showed no interest in small talk, was often told she "should have been born a man", as recounted by an article entitled "Illusions and delusions of a masculinised lady" 57 : her brilliant achievements are described as the abilities of a freak and are somehow ridiculed. A young Piedmontese woman, "educated abroad", is signalled to have appeared in Calcutta, as the Italian Consul reports: "she demonstrates no Italianity feelings and, for the life-style she leads, has generated serious suspicions in the local English community". ${ }^{8}$ Women who socialised without the presence of men generated concern: on one instance a "ladies only club" was investigated but turned out to be a clandestine brothel. ${ }^{59}$ On another case, an anonymous letter denounced a woman who hosted regular gatherings of women in her apartment, but it turned out that she was giving German lessons to a group of friends. ${ }^{60}$

Silence was not completely impenetrable, though, and people heard about what was going on, in their town and elsewhere, among them queer people in particular, since some form of a circuit existed and rumours of blackmailing and intimidations circulated. For instance, although it had never happened to her, another person who accepted to be interviewed between 2006 and 2010, MtoF transsexual Lucy, knew of black shirts ambushing gay men and she was aware of beatings of the more visible ones in Bologna. ${ }^{61}$ She, at the time a young boy, also knew of some local homosexuals who had been sent to confino, although she did not frequent them.

Even within the constraints imposed upon historical research on sexuality in Italy, ${ }^{62}$ Milan, Venice, Florence, Bologna and Catania now have a partially documented queer "scene", whose meeting places, cruising areas, bars and hotels have been identified. ${ }^{63}$ Little is known about Turin, but 
It would appear that sad manifestations of pederasty are rampant: Alfredo F., who is a technician of this activity [sic!], says it is widely practiced in Venice, in Turin, in Milan, areas and towns he frequents as he is a variety shows artist. $^{64}$

Besides, if extortion of gay men took place in day-light, other homosexuals are likely to have been blackmailed and Parco Michelotti must have been a credible location to mention when referring to a meeting place for men who wanted sex with other men. If three men were arrested and sentenced to confino for "acts contrary to buon costume" 195 in 1940 in the Borgo Dora area, a bushy area around a river, this plausibly was a meeting spot already in the early fascist era. During the Ventennio four Turinese female friends are likely to have formed two lesbian couples, as immediately after World War II, two of them, sisters at birth, were reported to have "become brothers" and "now named Luigi and Lino" were "engaged to be married to girls they knew when they were all officially of the same sex". ${ }^{66}$ And finally, queer men and women must have had parties where they danced together, if at the end of the dictatorship and in the middle of the war they still found the enthusiasm and urge to gather, listen to music and be together. The Turin Prefettura Archives reveal that 12 young men were arrested and three of them deported to Germany for having done just that. ${ }^{67}$

$\mathrm{G}$. is likely to have known that, by insisting on deserving compensation for the discrimination he had suffered at the hands of his brother, he was risking a lot. He was certainly aware of the possible consequences of a public disclosure of his past homosexual liaisons. Yet, he decided to go ahead, as he also must have thought he had nothing left to lose: he had no job, no money, no fixed address, his father had disinherited him and probably all these conditions were caused by his homosexuality becoming known. Many men and women are likely to have been in a similar situation at the time. The really unique fact is that G. rebelled against silence. He wrote this clearly at the end of his long memoriale: he described himself as "one of the many victims who does not want to disappear" ${ }^{68}$ So, despite feeling, understandably, cornered, he refused to admit defeat and prepared to fight his desperate battle against injustice, his brother and the repressive system he represented.

This chapter painted the backdrop of the memoriale and gave an idea of what it must have felt like to live in Italy in 1928, especially as a homosexual: pressure was increasing in all areas of life, the dictatorship was 
crucially transforming private choices into gestures of responsibility of every citizen towards the state. The following chapter focuses on G.'s internment and draws the picture of what happened within the Collegno asylum's walls.

\section{Notes}

1. Vincy, R. 1928. Tu Soffrirai. La Gazzetta del Popolo, November 22, p. 8.

2. Both AST, FP-GIV, b. 170, Ordine Pubblico.

3. 1928. Le Ultime Trincere (sic) dell'Antifascismo. La Stampa, November 22, p. 2.

4. Ibid., p. 3.

5. I piccioni. Lettere del pubblico, Ibid., p. 6.

6. Tre processi al Tribunale Speciale, Ibid., p. 4.

7. Ebner, Michael, 2011, op. cit.

8. 1926. Editori e Librai processati per offesa al pudore. La Gazzetta del Popolo, January 13, p. 6.

9. 1926. Letteratura non per Signorine in tribunale. La Stampa, January 3, p. 4.

10. 1926. La sorveglianza sulle sale da ballo. L'opera di epurazione compiuta a Torino. La Gazzetta del Popolo, January 19, p. 6.

11. Ibid.

12. AST, FP-GIV, b. 204, Ordine Pubblico, telegram Ministry of Interiors, 31.12.1926.

13. Ibid., telegram of Ministry of Interiors of 22.12.1926, n. 13,500.

14. 1928. Pro e contro il jazz-band. La Stampa, November 22, p. 6.

15. 1928. Nel quarto centenario della morte di Alberto Durero. L'Illustrazione Italiana LV, 48, November 25.

16. Murialdi, Paolo. 1980. La stampa quotidiana del regime fascista. In La Stampa Italiana nell'età fascista, Castronovo, Valerio and Tranfaglia, Nicola, eds. Bari: Laterza, p. 33.

17. AST, FP-GIV, b. 170 Ordine Pubblico, 9.8.1924.

18. Castronovo, Valerio and Tranfaglia, Nicola, op. cit.

19. AST, FP-GIV, b. 647, Scioglimento Circoli.

20. Ebner, Michael, 2011 , op. cit.

21. ATS, op. cit., b. 645 bis, Movimento sovversivi e Sequestro stampe.

22. On censorship during Fascism: Bonsaver, Guido. 2013. Mussolini censore. Storie di letteratura, dissenso e ipocrisia. Bari: Laterza; Castronovo, Valerio and Tranfaglia, Nicola, op. cit.; Forno, Mauro. 2005. La stampa del ventennio. Strutture e trasformazioni nello stato totalitario. Soveria Mannelli: Rubettino; Wanrooij, P.F. Bruno. 1990. Storia del pudore. La questione sessuale in Italia 1860-1940. Venezia: Marsilio. 
23. 1926. I “coriandoli” vietati. La Stampa, February 7, p. 6 and 1926. I coriandoli. La Stampa, February 8, p. 3.

24. Decreto Legge n. 2132, 19.12.1926.

25. Data provided by Ginsborg, Paul. 2014. Family Politics. Domestic Life, Devastation and Survival, 1900-1950. London and New Haven: Yale University Press.

26. Rocco Code, art. 554 and art. 552.

27. Dunnage, Jonathan. 2016. Policemen and "Women of Ill Repute": A Study of Male Sexual Attitudes and Behaviour in Fascist Italy. European History Quarterly 46 (I): 72-91, p. 75.

28. Passerini, Luisa. 1987. Fascism in Popular Memory. The Cultural Experience of the Turin Working Class. Cambridge: Cambridge University Press. I ed. 1984.

29. 1929. Le denunzie per l'imposta sui celibi. La Stampa, January 13, p. 5.

30. Cherubini, Bixio. Circa 1928. “Allegri Scapoli”. Milano: Rusconi.

31. De Grazia, Victoria, 1993. Le donne nel regime fascista. Venezia: Marsilio. I ed. 1992.

32. 1929. Il problema demografico a Torino e una nota del "Regime Fascista". La Stampa, March 14, p. 6.

33. ACS, Mostra della Rivoluzione fascista, b. 7, f. 7, Romagna, report of 1st February 1930, quoted p. 108 in Wanrooij, P.F. Bruno. 1990. op. cit.

34. De Grazia, Victoria, op. cit., p. 76.

35. 1929. Pericoli e insidie delle cosidette accademie di danza. La Stampa, December 8, p. 5.

36. AST, op. cit., b. 645 bis.

37. Ibid.

38. Ebner, Michael. 2011, op. cit.

39. See Chap. 6 and Petracci, Matteo, op. cit. Franzinelli, Mimmo and Graziano, Nicola. 2015. Un'Odissea Partigiana. Dalla Resistenza al Manicomio. Milano: Feltrinelli.

40. Quoted p. 146 in Forno, Mauro. 2005. La stampa del ventennio. Strutture e trasformazioni nello stato totalitario. Soveria Mannelli: Rubettino.

41. Benadusi, Lorenzo, op. cit.; Ebner, Michael. 2004, op. cit. Ebner notes the difference of sanctions but mistranslates "habitual homosexuals" as "men who engaged in consensual sex", thus slightly missing the point.

42. See Chap. 3.

43. Dall'Orto, Giovanni, op. cit.; Giartosio, Tommaso and Goretti, Gianfranco, op. cit.; Benadusi, Lorenzo, op. cit.; Rossi Barilli, Gianni, op. cit.; Ebner, Michael, 2004 and 2011, op. cit.

44. Ebner, Michael. 2004, op. cit., p. 144.

45. Benadusi, Lorenzo, op. cit.

46. Romano, Gabriella, 2003, op. cit.

47. Dunnage, Jonathan, op. cit., p. 80. 
48. Ebner, Michael. 2004, op. cit., p. 143.

49. Quoted in Benadusi, Lorenzo, op. cit., p 131.

50. Dunnage, Jonathan, op. cit., p. 74.

51. Benadusi, Lorenzo, op. cit.

52. Mosse, George, op. cit.

53. Both quoted in Benadusi, Lorenzo, op. cit.; the first, p. 128, is from Mussolini's "Discorso dell'Ascensione" pronounced on 26.5.1927, the second one, p. 131, is from Lussu, Emilio. 1945. La Catena. Firenze: Vallecchi. On Mussolini's use of the medical metaphor see Rigotti, F. 1987. Il medico-chirurgo dello Stato nel linguaggio metaforico di Mussolini. In Cultura e società negli anni del fascismo, Istituto lombardo per la storia del movimento di liberazione in Italia, ed. Milano: Cordani.

54. Dall’Orto, Giovanni. 1987, op. cit.; Rossi Barilli, Gianni, op. cit.

55. Quoted in Castronovo, Valerio and Tranfaglia, Nicola, op cit., p. 89.

56. 1929. L'estorsione di quattro giovinastri. La Gazzetta del Popolo, March 22 , p. 6.

57. 1929. Illusioni e delusioni di una signora mascolinizzata. La Stampa, March 2, p. 6.

58. AST, op. cit., b. 645 bis, 23.8.1930.

59. 1929. Un club per signore sole.La Gazzetta del Popolo, March 15, p. 6.

60. AST, op. cit., b. 645 bis, 1930.

61. Romano, Gabriella. 2009. Il mio nome è Lucy. L'Italia del XX secolo nei ricordi di una transessuale. Roma: Donzelli; Romano, Gabriella. 2011. "Essere Lucy", Video.

62. See Chap. 1.

63. Rossi Barilli, Gianni, op. cit.; Dall'Orto, Giovanni, op. cit.; Giartosio, Tommaso and Goretti, Gianfranco, op. cit.; Romano, Gabriella, 2011, op. cit.; Milletti, Nerina and Passerini, Luisa eds., op. cit.

64. Quoted in Benadusi, Lorenzo, op. cit., p. 181.

65. 1940. Tre persone arrestate per atti contro il buon costume. La Stampa, February 21, p. 5.

66. 1947. Sisters change sex. Two Italians engaged to girlhood friends. News of the World, March 9.

67. AST, op. cit., b. 204, Ordine Pubblico, 29.4.1944.

68. CA, G.'s memoriale, op. cit., p. 1.

\section{BIBLIOGRAPHY}

Benadusi, Lorenzo. 2005. Il nemico dell'uomo nuovo. L'omosessualità nell'esperimento totalitario fascista. Milano: Feltrinelli.

Bonsaver, Guido. 2013. Mussolini censore. Storie di letteratura, dissenso e ipocrisia. Bari: Laterza. 
Castronovo, Valerio and Tranfaglia, Nicola, eds. 1980. La stampa italiana nell'età fascista. Bari: Laterza.

Centini, Massimo. 2013. Bordelli torinesi. Quando le case chiuse erano aperte. Torino: Editrice Il Punto - Piemonte in Bancarella.

Corner, Paul. 2006. Everyday Fascism in the 1930s: Centre and Periphery in the Decline of Mussolini's Dictatorship. Contemporary European History 15 (2): $195-222$.

Dall'Orto, Giovanni. 1986a. Credere, Obbedire, Non Battere. Babilonia May: 13-17.

- 1986b. Per il bene della Razza al Confino il Pederasta. Babilonia AprilMay: 14-17.

- 1987a. Ci furono femminelle che piangevano quando venimmo via dalle Tremiti! Babilonia October: 26-28.

—. 1987b. La 'Tolleranza Repressiva' dell'Omosessualità. Quaderni di Critica Omosessuale 3: 37-57.

- 2015. Tutta un'altra storia. L'omosessualità dall'antichità al secondo dopoguerra. Milano: Il Saggiatore.

De Grazia, Victoria. 1993. Le donne nel regime fascista. Venezia: Marsilio. I ed. 1992.

Duggan, Christopher. 2013. Fascist Voices. An Intimate History of Mussolini's Italy. Oxford and New York: Oxford University Press. I ed. 2012.

Dunnage, Jonathan. 2016. Policemen and "Women of Ill Repute": A Study of Male Sexual Attitudes and Behaviour in Fascist Italy. European History Quarterly 46 (I): 72-91.

Durham, Martin. 1998. Women and Fascism. London and New York: Routledge.

Ebner, Michael. 2004. The Persecution of Homosexual Men Under Fascism. In Gender, Family and Sexuality. The Private Sphere in Italy 1860-1945, Wilson, Perry, ed. Basingstoke: Palgrave Macmillan.

- 2011. Ordinary Violence in Mussolini's Italy. Cambridge: Cambridge University Press.

Forno, Mauro. 2005. La stampa del ventennio. Strutture e trasformazioni nello stato totalitario. Soveria Mannelli: Rubettino.

Giartosio, Tommaso and Goretti, Gianfranco. 2006. La città e l'Isola. Roma: Donzelli.

Goetz, Helmut. 2000. Il giuramento rifiutato. I docenti universitari e il regime fascista. Milano: La Nuova Italia. I ed. 1993.

Milletti, Nerina and Passerini, Luisa, eds. 2007. Fuori dalla Norma. Storie lesbiche nell'Italia del primo Novecento. Torino: Rosenberg\&Sellier.

Signoretti, Alfredo. 1968. La stampa in camicia nera 1932-1943. Roma: Giovanni Volpe Editore.

Venè, Gian Franco. 1988. Mille Live al mese. Vita quotidiana della famiglia nell'Italia fascista. Milano: Arnoldo Mondadori. 
Wanrooij, P.F. Bruno. 1990. Storia del pudore. La questione sessuale in Italia 1860-1940. Venezia: Marsilio.

1999. Italy: Sexuality, Morality and Public Authority. In Sexual Cultures in Europe, Eder, Franz, Hall, Leslie, et al., eds. Manchester: Manchester University Press.

Open Access This chapter is licensed under the terms of the Creative Commons Attribution 4.0 International License (http://creativecommons.org/licenses/ by $/ 4.0 /$ ), which permits use, sharing, adaptation, distribution and reproduction in any medium or format, as long as you give appropriate credit to the original author(s) and the source, provide a link to the Creative Commons license and indicate if changes were made.

The images or other third party material in this chapter are included in the chapter's Creative Commons license, unless indicated otherwise in a credit line to the material. If material is not included in the chapter's Creative Commons license and your intended use is not permitted by statutory regulation or exceeds the permitted use, you will need to obtain permission directly from the copyright holder.

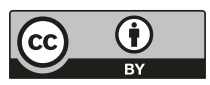

